\title{
Pengaruh pemberian makanan tambahan (PMT) pada ibu hamil terhadap berat lahir bayi
}

The effect of supplementary feeding for pregnant women on birth weight

Hana Shafiyyah Zulaidah ${ }^{1}$, Istiti Kandarina², Mohammad Hakimi ${ }^{1}$

\begin{abstract}
Background: Anemia causes fetal growth disorders that affect birth weight. Antenatal care (ANC) coverage and provision of high $\mathrm{Fe}$ if not followed by a decrease in the incidence of anemia can result indirectly in the risk of low birth weight. Supplementary feeding is expected to resolve the issue. Objective: To assess the effect of supplementary feeding on third trimester of pregnancy on birth weight. Method: This was a quantitative study with a study design of quasi-experiment and non-equivalent control group. The given intervention was fish-processed feeding for 30 days. The study population were pregnant women in the third trimester in all health centers in the City of Yogyakarta and the samples were 104 pregnant women in some health centers with convenience sampling technique. The subjects were divided into two, namely the treatment group (PMT) and the comparison group (non PMT). Birth weight was weighed immediately after the baby was born. Statistical analysis used t-test and logistic regression. Results: The mean birth weight of infants in the treatment group and the comparison group was $3248 \mathrm{~g}$ and $2974 \mathrm{~g}$, respectively, so that the difference in the mean birth weight of both groups was $274 \mathrm{~g}$ ( $p=0.0002 ; 95 \%$ C:131-416). Thus, supplementary feeding was shown significantly affect the birth weight. The extraneous variables that significantly influenced birth weight were pregnancy interval. Other extraneous variables were age, mid-upper-arm circumference (MUAC), education, occupation, economic status, parity, protein intake, compliance of $F$ e tablet intake, antenatal care, gestational age at delivery and anemia status were not proven statistically significant to affect birth weight. Conclusion: Supplementary feeding effect on birth weight.
\end{abstract}

KEY WORDS: supplementary feeding, anemia, pregnant women, birth weight

\begin{abstract}
ABSTRAK
Latar belakang: Anemia menyebabkan gangguan tumbuh kembang janin yang berpengaruh pada berat lahir bayi. Cakupan antenatal care (ANC) dan pemberian Fe yang tinggi, tidak diikuti dengan menurunnya kejadian anemia kehamilan yang berakibat secara tidak langsung terhadap risiko berat lahir bayi yang rendah (BBLR). Pemberian makanan tambahan (PMT) diharapkan mampu mengatasi masalah tersebut. Tujuan: Mengkaji pengaruh PMT pada ibu hamil trimester III terhadap berat lahir bayi. Metode: Penelitian kuantitatif dengan rancangan quasi experiment dan desain non-equivalent control group. Intervensi yang dilakukan adalah pemberian makanan olahan ikan selama 30 hari. Populasi penelitian adalah ibu hamil trimester III di seluruh puskesmas di Kota Yogyakarta dengan sampel sebanyak104 ibu hamil di beberapa puskesmas dengan teknik convenience sampling. Subjek penelitian dibagi menjadi dua yaitu kelompok perlakuan dan pembanding. Berat lahir bayi ditimbang segera setelah bayi dilahirkan. Analisis data menggunakan $t$-test dan regresi logistik. Hasil: Rerata berat lahir bayi pada kelompok perlakuan adalah

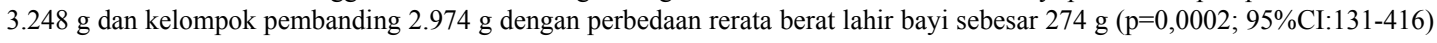
sehingga PMT terbukti secara signifikan berpengaruh terhadap berat lahir bayi. Variabel luar yang berpengaruh secara signifikan terhadap berat lahir bayi yaitu jarak kehamilan. Variabel luar lainnya yaitu umur, pendidikan, pekerjaan, status ekonomi, lingkar lengan atas (LILA), asupan protein, kunjungan ANC, kepatuhan konsumsi tablet $\mathrm{Fe}$, paritas, umur kehamilan, dan status anemia secara statistik tidak terbukti signifikan berpengaruh terhadap berat lahir bayi. Simpulan: Pemberian makanan tambahan kepada ibu hamil trimester III dapat meningkatkan berat lahir bayi.
\end{abstract}

KATA KUNCI: pemberian makanan tambahan, anemia, ibu hamil, berat lahir bayi

\footnotetext{
Korespondensi: Minat Kesehatan Ibu dan Anak-Kesehatan Reproduksi (KIA-KR), Program Studi S2 Ilmu Kesehatan Masyarakat, Fakultas Kedokteran, Universitas Gajah Mada, Jl. Farmako, Sekip Utara, Yogyakarta 55281, e-mail: shafiyyah_hz@yahoo.co.id

2 Minat Gizi dan Kesehatan, Program Studi S2 Ilmu Kesehatan Masyarakat, Fakultas Kedokteran Universitas Gadjah Mada, Jl. Farmako, Sekip Utara, Yogyakarta 55281, e-mail: ikandarina@yahoo.com
} 


\section{PENDAHULUAN}

Anemia menjadi masalah kesehatan utama dan mendasar karena dapat mempengaruhi kesehatan dan kualitas hidup seseorang. Ibu hamil yang menderita anemia berisiko lebih tinggi terhadap kematian dan dapat berdampak buruk terhadap pertumbuhan dan perkembangan janin yang dikandungnya (1). Peningkatan kebutuhan yang tidak diimbangi dengan peningkatan cadangan zat besi (Fe) dalam tubuh merupakan penyebab utama terjadinya anemia selama kehamilan. Pertumbuhan janin selama masa kehamilan berpengaruh terhadap berat lahir bayi (2). Anemia yang terjadi pada kehamilan meningkatkan risiko terjadinya berat badan lahir rendah (BBLR) (3). Pada tahun 2010, prevalensi kejadian BBLR di Indonesia sebesar 8,8\% (4) dan di Kota Yogyakarta pada tahun 2012 sebanyak 3,8\% (5).

Gizi yang baik merupakan salah satu faktor yang dibutuhkan untuk mencegah terjadinya anemia pada kehamilan (6). Pemberian makanan tambahan (PMT) bertujuan untuk mencukupi kebutuhan gizi ibu selama masa kehamilan terutama kecukupan protein (7). Waktu yang tepat dalam pelaksanaan PMT sebagai program suplementasi gizi untuk ibu hamil yaitu pada trimester II dan III karena pada usia kehamilan tersebut kebutuhan gizi meningkat dan pertumbuhan janin berjalan cepat (8). Tujuan penelitian ini adalah untuk mengkaji pengaruh PMT pada ibu hamil trimester III terhadap berat lahir bayi. Hipotesis penelitiannya yaitu rerata berat lahir bayi pada kelompok yang diberi makanan tambahan lebih tinggi dibandingkan rerata berat lahir bayi pada kelompok kontrol.

\section{BAHAN DAN METODE}

Jenis penelitian ini adalah penelitian kuantitaf dengan rancangan penelitian quasi experiment. Desain yang digunakan yaitu non equivalent control group yaitu membandingkan hasil intervensi pada dua kelompok yaitu kelompok kontrol tidak harus benar-benar sama dan pengelompokan tidak dilakukan secara random (9). Intervensi yang dilakukan dalam penelitian ini adalah PMT selama 30 hari pada ibu hamil trimester III. Makanan tambahan yang diberikan merupakan 5 macam makanan olahan berbahan dasar ikan tuna yaitu otak-otak, nugget, kaki naga, aji furai, dan rolade yang diproduksi oleh Jurusan Perikanan Fakultas Pertanian Universitas Gadjah Mada (UGM). Makanan diberikan setiap hari antara waktu makan pagi dan makan siang dan diharapkan mencukupi 30-50\% tambahan kebutuhan protein ibu hamil.

Populasi dalam penelitian ini adalah seluruh ibu hamil trimester III di seluruh puskesmas di Kota Yogyakarta. Subjek penelitian yaitu individu dalam populasi yang memenuhi kriteria inklusi dan eksklusi. Kriteria inklusi yaitu ibu hamil tidak mengalami kurang energi kronis (KEK); menerima tablet Fe; merencanakan persalinan di Kota Yogyakarta; dan bersedia menjadi subjek penelitian dengan menandatangi informed consent. Kriteria eksklusi yaitu subjek pindah alamat sehingga sulit dilacak; subjek terdiagnosis penyakit tertentu yang berbahaya bagi kehamilan yaitu penyakit sistemis (diabetes, lupus) dan penyakit infeksi (malaria, HIV-AIDS, cacar); mengalami kelainan darah (kelainan penjendalan darah, thalasemia); dan subjek merencanakan persalinan caesar. Besar sampel penelitian diperoleh menggunakan perhitungan rumus beda rata-rata dua populasi (10), dengan outcome yang diamati adalah selisih rata-rata berat lahir bayi antara kelompok perlakuan dengan kelompok pembanding $\left(\mu_{1}-\mu_{2}\right)$ sebesar 250 dan standar deviasi sebesar 424 yang mengacu pada penelitian sebelumnya (11) sehingga jumlah sampel minimal yang diperlukan adalah $46 \mathrm{ibu}$ hamil. Mengantisipasi terjadinya drop out dan loss to follow up maka perlu dilakukan koreksi terhadap besar sampel dengan menambahkan sejumlah subjek agar besar sampel tetap terpenuhi sehingga jumlah subjek penelitian untuk setiap kelompok sebanyak 52 orang. Teknik yang digunakan dalam pengambilan sampel penelitian yaitu teknik convenience sampling.

Penelitian dilaksanakan di Kota Yogyakarta mulai bulan Agustus - Desember 2013. Variabel bebas dalam penelitian ini yaitu PMT dengan kandungan gizi dari masing-masing makanan olahan terangkum dalam Tabel 1 sedangkan variabel terikat adalah berat lahir bayi. Variabel luarnya meliputi umur, pendidikan, pekerjaan, status ekonomi, lingkar lengan atas (LILA), asupan protein, kunjungan antenatal care (ANC), kepatuhan konsumsi tablet $\mathrm{Fe}$, paritas, jarak kehamilan, status anemia, umur kehamilan, dan jenis kelamin bayi. 
Hana Shafiyyah Zulaidah, dkk: Pengaruh pemberian makanan tambahan (PMT) pada ibu hamil terhadap berat lahir bayi

Tabel 1. Kandungan gizi makanan tambahan

\begin{tabular}{lccccc}
\hline \multirow{2}{*}{ Produk } & $\begin{array}{c}\text { Kadar } \\
\text { air }\end{array}$ & $\begin{array}{c}\text { Kadar } \\
\text { abu }\end{array}$ & $\begin{array}{c}\text { Kadar } \\
\text { protein }\end{array}$ & $\begin{array}{c}\text { Kadar } \\
\text { lemak }\end{array}$ & $\begin{array}{c}\text { Kadar } \\
\text { karbohidrat }\end{array}$ \\
\cline { 2 - 6 } & $\mathbf{( \% )}$ & $\mathbf{( \% )}$ & $\mathbf{( \% )}$ & $\mathbf{( \% )}$ & $\mathbf{( \% )}$ \\
\hline Aji furai & 61,54 & 3,28 & 9,88 & 3,44 & 21,86 \\
Nugget & 49,90 & 1,65 & 14,65 & 3,53 & 30,27 \\
Kaki naga & 44,39 & 2,98 & 11,11 & 8,08 & 33,44 \\
\hline Otak-otak & 61,80 & 1,66 & 15,15 & 4,63 & 16,76 \\
\hline
\end{tabular}

Pemberian makanan tambahan adalah pemberian makanan selain makanan utama atau pokok yang diberikan pada ibu hamil selama 30 hari yang merupakan 5 macam produk olahan dari ikan tuna. Kelompok PMT yaitu kelompok perlakuan yang diberi makanan tambahan setiap hari selama 30 hari sedangkan kelompok kontrol tidak diberi makanan tambahan, tetapi hanya dipantau konsumsi tablet Fe setiap hari selama 30 hari. Pembagian kelompok berdasarkan pada lokasi tempat tinggal ibu. Berat lahir bayi merupakan berat bayi yang ditimbang maksimal satu jam setelah bayi lahir dalam satuan gram (g) (12).

Sebelum makanan tambahan diberikan kepada ibu hamil sebagai intervensi dari penelitian ini, peneliti telah melakukan uji penerimaan dan kesukaan makanan kepada ibu hamil di populasi lain yang bukan merupakan tempat penelitian. Hasil uji ini menyatakan bahwa semua ibu menyukai makanan yang diberikan akan tetapi dengan beberapa perbaikan seperti pengurangan pengunaan jahe pada aji furai karena terlalu pedas dan penambahan garam pada nugget karena rasanya kurang asin serta bentuk yang kurang menarik dari otak-otak. Makanan yang paling digemari dari lima jenis makanan yang diberikan (berdasarkan perhitungan skor) secara berurutan dari yang paling disukai yaitu rolade, aji furai, kaki naga, nugget, otak-otak.

Intervensi PMT pada ibu hamil trimester III dengan anemia diberikan sebanyak 30 kali dengan intensitas waktu setiap hari selama 30 hari. Lama waktu pemberian makanan ini berdasarkan pada penelitian sebelumnya yaitu penelitian tentang PMT pada ibu hamil dengan KEK yang dilakukan di Kabupaten Takalar, Sulawesi Selatan (13). Makanan akan diberikan dengan siklus lima hari sesuai dengan jumlah jenis makanannya. Makanan diberikan dengan cara berselang-seling dengan tujuan untuk menghindari kebosanan ibu hamil dalam mengkonsumsi makanan tambahan tersebut. Jumlah makanan yang diberikan untuk setiap produk berbeda-beda. Hal ini berkaitan dengan harga dan berat dari makanan tambahan tersebut. Rerata berat makanan tambahan yang diberikan setiap hari adalah $50 \mathrm{~g}$ dengan unit cost antara Rp 5.000,- sampai dengan Rp 6.500,-. Pendistribusian makanan akan dilakukan oleh peneliti dan bantuan enumerator. Makanan diberikan setiap pagi pada selang waktu antara makan pagi dan makan siang. Peneliti atau enumerator memberikan dan menunggu ibu mengkonsumsinya langsung. Hal ini berkaitan dengan penilaian kepatuhan ibu dalam mengkonsumsi makanan tambahan. Apabila waktu konsumsi makanan tambahan tidak dilakukan pengamatan, dikhawatirkan makanan yang diberikan tidak hanya dikonsumsi oleh ibunya saja atau makanan justru sama sekali tidak dikonsumsi.

Jenjang pendidikan tertinggi yang ditamatkan oleh ibu hamil ditandai dengan ijazah (14), dikategorikan menjadi tinggi (SMU dan perguruan tinggi) dan rendah (tidak sekolah, SD, dan SMP). Status ekonomi yaitu kemampuan keluarga untuk memenuhi kebutuhan baik pangan maupun non-pangan yang diukur dengan pendapatan rata-rata per bulan berdasarkan UMR yang berlaku di Kota Yogyakarta (Rp 1.065.000,-). Status gizi yaitu keadaan gizi ibu hamil yang dinilai dari salah satu pengukuran antropometri yaitu LILA. Pengukuran LILA dilakukan pada pertengahan antara pangkal lengan atas dan ujung siku tangan kanan yang diukur menggunakan alat pita metlin dalam satuan $\mathrm{cm}$. Asupan protein adalah rerata konsumsi harian protein ibu hamil yang diketahui melalui food recall 24 jam dan dilakukan sebanyak 7 kali. Data tersebut menggunakan ukuran rumah tangga (URT) yang kemudian dikonversi kedalam satuan $g$ dan dianalisis menggunakan software nutrisurvey. Kunjungan ANC yaitu frekuensi pemeriksaan kehamilan pada trimester pertama sampai dengan trimester ketiga, diketahui dari buku kesehatan ibu dan anak (KIA) dengan kategori baik ( 2 kali) dan kurang baik ( $<2$ kali). Kepatuhan konsumsi tablet Fe diketahui dari hasil observasi yang dilakukan oleh peneliti dan enumerator. Ibu hamil dikategorikan patuh apabila mengkonsumsi tablet Fe setiap hari selama 30 hari dan tidak patuh apabila dalam waktu 30 hari, pernah tidak mengkonsumsi tablet Fe. Jarak kehamilan adalah rentang waktu antara tanggal 
lahir anak terakhir dengan hari perkiraan haid terakhir yang dibedakan menjadi 2 tahun; kurang dari 2 tahun; dan kehamilan pertama. Status anemia yaitu kondisi ibu hamil trimester III dengan kadar hemoglobin ( $\mathrm{Hb})$ kurang dari $11 \mathrm{~g} / \mathrm{dl}$ pada awal penelitian yang diketahui dari hasil pengukuran kadar $\mathrm{Hb}$ menggunakan alat quick check. Umur kehamilan merupakan ukuran lama waktu seorang janin berada dalam rahim. Umur kehamilan dihitung dalam minggu dari hari pertama menstruasi terakhir (HPMT) ibu sampai persalinan yang diperoleh dari buku KIA yang dilihat setelah ibu bersalin.

Instrumen yang digunakan yaitu formulir wawancara, formulir recall 24 jam, timbangan bayi, quick check, serta alat untuk menyimpan, menggoreng, dan mengemas PMT bagi ibu hamil. Wawancara termasuk recall 24 jam dilakukan oleh peneliti, penimbangan bayi dilakukan maksimal satu jam setelah bayi lahir oleh tenaga kesehatan penolong persalinan. Analisis data menggunakan $t$-test, regresi linear, dan One-way ANOVA untuk analisis bivariat serta multiple regression untuk analisis multivariat. Penelitian ini telah mendapat surat kelayakan atau persetujuan etik penelitian dari Komisi Etik Penelitian Kedokteran dan Kesehatan Fakultas Kedokteran UGM.

\section{HASIL}

Jumlah keseluruhan ibu hamil trimester III dengan hari perkiraan lahir (HPL) bulan Oktober dan November 2013 di Kota Yogyakarta berdasarkan data yang terdapat dalam buku kohort di Puskesmas adalah 128 ibu hamil. Ibu hamil yang menjadi subjek penelitian merupakan ibu hamil yang memenuhi kriteria inklusi dan eksklusi, dari 128 ibu hamil diperoleh subjek sebanyak $104 \mathrm{ibu}$ hamil. Jumlah subjek penelitian yang diteliti sampai akhir penelitian untuk kelompok kontrol yaitu 52 orang, tetapi pada kelompok perlakuan menjadi 49 orang. Hal ini karena terdapat tiga ibu yang drop out.

Berdasarkan Tabel 2 dapat diketahui bahwa hanya variabel status ekonomi dan kepatuhan konsumsi tablet Fe saja yang tidak homogen karena ada perbedaan persentase yang cukup besar antara kelompok perlakuan dan kelompok kontrol $(\mathrm{p}<0,05)$. Lebih lanjut, hasil analisis $t$-test dilakukan untuk melihat pengaruh variabel bebas yaitu PMT terhadap variabel terikat yaitu berat lahir bayi. Rerata berat lahir bayi pada kelompok perlakuan adalah $3.248 \mathrm{~g}$ dan pada kelompok kontrol adalah 2.974 g. Berdasarkan hasil tersebut diketahui bahwa rerata berat lahir bayi pada kelompok perlakuan lebih tinggi dibandingkan dengan kelompok kontrol dengan selisih atau beda rata-rata antara dua kelompok sebesar $274 \mathrm{~g}$ ( $p=0,0002 ; 95 \% \mathrm{CI}: 131-416$ ) yang berarti secara statistik ada pengaruh PMT terhadap berat lahir bayi. Selisih sebesar 274 g juga sejalan dengan harapan peneliti untuk meningkatkan berat lahir bayi minimal sebesar $250 \mathrm{~g}$ setelah diberi makanan tambahan selama 30 hari pada trimester III sehingga dapat disimpulkan bahwa PMT ini secara klinis berpengaruh terhadap berat lahir bayi.

Analisis bivariat yang digunakan selanjutnya adalah uji t-test untuk melihat pengaruh variabel luar dengan data yang bersifat kategorik terhadap berat lahir bayi (Tabel 3). Variabel luar yang secara statistik signifikan $(p<0,05)$ terhadap berat lahir bayi yaitu jarak kehamilan dan jenis kelamin bayi. Hasil analisis data antara jarak kehamilan yang dibagi menjadi 3 kategori terhadap berat lahir bayi menunjukan nilai $\mathrm{p}=0,140$ untuk jarak kehamilan kurang dari 2 tahun dan nilai $p=0,010$ untuk kehamilan pertama sehingga dapat diartikan bahwa secara statistik rerata berat lahir bayi dari ibu dengan jarak kehamilan lebih dari atau sama dengan 2 tahun hanya signifikan jika dibandingkan dengan rerata berat lahir bayi dari ibu yang baru mengalami kehamilan pertama. Namun, jika dilihat secara klinis perbedaan rerata berat lahir bayi pada kategori jarak kehamilan kurang dari 2 tahun dan kehamilan pertama terhadap kategori jarak kehamilan lebih dari atau sama dengan 2 tahun, nilainya lebih dari $200 \mathrm{~g}$ sehingga secara klinis terdapat perbedaan. Hasil analisis menunjukan rerata berat lahir bayi laki-laki lebih besar $158 \mathrm{~g}$ dibandingkan berat lahir bayi perempuan ( $\mathrm{p}<0,05$; 95\%CI:9-307) sehingga dapat ditarik kesimpulan bahwa jenis kelamin secara statistik berpengaruh signifikan terhadap berat lahir bayi.

Tabel 4 memperlihatkan bahwa ada hubungan yang berbanding lurus antara variabel umur, asupan protein, paritas, dan umur kehamilan dengan berat lahir bayi yang berarti setiap kenaikan umur ibu, asupan protein, paritas, dan umur kehamilan akan meningkatkan berat lahir bayi. Namun, kenaikannya masih relatif kecil sehingga secara klinis tidak mempunyai pengaruh yang signifikan. Status 
Tabel 2. Uji homogenitas variabel pendidikan, pekerjaan, status ekonomi, kunjungan ANC, jarak kehamilan, kepatuhan konsumsi tablet $\mathrm{Fe}$, jenis kelamin bayi, dan status anemia menurut kelompok intervensi pada ibu hamil trimester III

\begin{tabular}{|c|c|c|c|c|}
\hline \multirow[b]{2}{*}{ Variabel } & \multicolumn{2}{|c|}{ Kelompok intervensi } & \multirow{2}{*}{$\begin{array}{c}\text { Nilai } \\
\text { statistik }\end{array}$} & \multirow[b]{2}{*}{$\mathbf{p}$} \\
\hline & $\begin{array}{c}\text { Perlakuan } \\
\text { n (\%) }\end{array}$ & $\begin{array}{c}\text { Kontrol } \\
\text { n (\%) }\end{array}$ & & \\
\hline Umur (tahun) (rerata \pm SD) & $30 \pm 0,79$ & $28 \pm 0,84$ & $1,0^{\mathrm{T}}$ & 0,304 \\
\hline \multicolumn{5}{|l|}{ Pendidikan } \\
\hline Tinggi (SMA, PT) & $39(79,6)$ & $37(71,1)$ & $0,9^{\mathrm{C}}$ & 0,326 \\
\hline Rendah (SD, SMP) & $10(20,4)$ & $15(28,9)$ & & \\
\hline \multicolumn{5}{|l|}{ Pekerjaan } \\
\hline Tidak bekerja & $30(61,2)$ & $32(61,5)$ & $0,0^{\mathrm{C}}$ & 0,974 \\
\hline Bekerja & $19(38,8)$ & $20(38,5)$ & & \\
\hline \multicolumn{5}{|l|}{ Status ekonomi } \\
\hline$\geq \operatorname{Rp} 1.065 .000,-$ & $26(53,0)$ & $39(75,0)$ & $5,2^{\mathrm{C}}$ & 0,021 \\
\hline$<\operatorname{Rp} 1.065 .000 .-$ & $23(47,0)$ & $13(25,0)$ & & \\
\hline LILA $(\mathrm{cm})($ rerata \pm SD $)$ & $26 \pm 0,38$ & $26 \pm 0,42$ & $-0,2^{\mathrm{T}}$ & 0,791 \\
\hline Asupan protein $(\mathrm{g})($ rerata \pm SD) & $58 \pm 3,79$ & $49 \pm 2,12$ & $2,0^{\mathrm{T}}$ & 0,041 \\
\hline \multicolumn{5}{|l|}{ Kunjungan ANC } \\
\hline Baik (4 kali) & $46(93,9)$ & $50(96,1)$ & $2,0^{\mathrm{T}}$ & 0,598 \\
\hline Kurang baik $(<4$ kali) & $3(6,1)$ & $2(3,9)$ & & \\
\hline \multicolumn{5}{|l|}{ Kepatuhan tablet $\mathrm{Fe}$} \\
\hline Patuh & $42(85,7)$ & $34(65,4)$ & $5,5^{\mathrm{C}}$ & 0,018 \\
\hline Tidak patuh & $7(14,3)$ & $18(34,6)$ & & \\
\hline Paritas (kali) (rerata \pm SD) & $1 \pm 0,12$ & $1 \pm 0,14$ & $0,2^{\mathrm{T}}$ & 0,773 \\
\hline \multicolumn{5}{|l|}{ Jarak kehamilan (tahun) } \\
\hline$\geq 2$ & $31(63,3)$ & $23(44,2)$ & $3,6^{\mathrm{C}}$ & 0,159 \\
\hline$<2$ & $3(6,1)$ & $5(9,6)$ & & \\
\hline Kehamilan pertama & $15(30,6)$ & $24(46,2)$ & & \\
\hline \multicolumn{5}{|l|}{ Status anemia } \\
\hline Anemia & $23(46,9)$ & $23(46,2)$ & $0,0^{\mathrm{C}}$ & 0,937 \\
\hline Tidak anemia & $26(53,1)$ & $28(53,8)$ & & \\
\hline Umur kehamilan (minggu) (rerata \pm SD) & $39 \pm 0,18$ & $39 \pm 0,17$ & $-0,0^{\mathrm{T}}$ & 0,951 \\
\hline \multicolumn{5}{|l|}{ Jenis kelamin bayi } \\
\hline Laki-laki & $26(53,1)$ & $28(53,8)$ & $0,2^{\mathrm{C}}$ & 0,617 \\
\hline Perempuan & $23(46,9)$ & $27(51,9)$ & & \\
\hline
\end{tabular}

Keterangan: $\mathrm{SD}=$ standar deviasi; homogen jika $\mathrm{p}>0,05$; Nilai statistik $(\mathrm{T}=$ t-test, $\mathrm{C}=$ Chi-Square $)$

gizi ibu berdasarkan LILA menunjukkan hubungan yang berbanding terbalik yaitu semakin besar LILA sebanyak $1 \mathrm{~cm}$ maka berat lahir bayinya justru akan $2 \mathrm{~g}$ lebih kecil tetapi perbedaan ini secara statistik tidak signifikan.

Analisis selanjutnya adalah analisis stratifikasi menggunakan $t$-test yang bertujuan untuk mengetahui apakah terdapat interaksi antara anemia yang dialami oleh ibu hamil pada awal penelitian dengan berat lahir bayi (Tabel 5). Rerata berat lahir bayi pada ibu yang tidak mengalami anemia pada kelompok perlakuan lebih besar $177 \mathrm{~g}$ dibandingkan rerata berat lahir bayi pada ibu di kelompok kontrol tetapi statistik rerata tidak signifikan ( $p>0,05)$. Ibu yang mengalami anemia pada kelompok perlakuan memiliki bayi dengan berat lahir $358 \mathrm{~g}$ lebih besar dibandingkan ibu yang mengalami anemia pada kelompok kontrol ( $\mathrm{p}=0,0002$; 95\%CI:177538) sehingga dapat diambil kesimpulan bahwa ada interaksi antara status anemia dengan pengaruh PMT terhadap berat lahir bayi. Hal ini menunjukan bahwa untuk ibu hamil yang mengalami anemia perlu peningkatan PMT sehingga bayi yang dilahirkan lebih besar berat lahirnya. 
Hana Shafiyyah Zulaidah, dkk: Pengaruh pemberian makanan tambahan (PMT) pada ibu hamil terhadap berat lahir bayi

Tabel 3. Pengaruh variabel luar terhadap berat lahir bayi

\begin{tabular}{|c|c|c|c|c|c|}
\hline \multirow{2}{*}{ Variabel } & \multicolumn{5}{|c|}{ Berat lahir bayi (g) } \\
\hline & Rerata & SD & Beda rerata & $95 \% \mathrm{CI}$ & $\mathbf{p}$ \\
\hline \multicolumn{6}{|l|}{ Pendidikan } \\
\hline Tinggi (SMA, PT) & 3125 & 44,3 & $72^{\#}$ & $-104-247$ & 0,420 \\
\hline Rendah (SD, SMP) & 3054 & 75,4 & & & \\
\hline \multicolumn{6}{|l|}{ Pekerjaan } \\
\hline Tidak bekerja & 3103 & 51,1 & $-11^{\#}$ & $-167-145$ & 0,891 \\
\hline Bekerja & 3114 & 57,1 & & & \\
\hline \multicolumn{6}{|l|}{ Status ekonomi } \\
\hline$\geq \operatorname{Rp} 1.065 .000,-$ & 3086 & 48,1 & $-61^{\#}$ & $-219-97$ & 0,447 \\
\hline$<\mathrm{Rp} 1.065 .000 .-$ & 3147 & 62,9 & & & \\
\hline \multicolumn{6}{|l|}{ Kunjungan ANC } \\
\hline Baik (4 kali) & 3135 & 39,5 & $82^{\#}$ & $-269-432$ & 0,645 \\
\hline Kurang baik $(<4$ kali) & 3023 & 143,7 & & & \\
\hline \multicolumn{6}{|l|}{ Jarak kehamilan (tahun) } \\
\hline$\geq 2$ & 3204 & 399,5 & & & \\
\hline$<2$ & 2994 & 200,8 & $-210^{¥}$ & $-491-70$ & 0,140 \\
\hline Kehamilan pertama & 2997 & 358,5 & $-207^{*}$ & $-363-52$ & $0,010^{*}$ \\
\hline \multicolumn{6}{|l|}{ Kepatuhan tablet Fe } \\
\hline Patuh & 3135 & 43,5 & $112^{\#}$ & $-63-287$ & 0,208 \\
\hline Tidak patuh & 3023 & 78,2 & & & \\
\hline \multicolumn{6}{|l|}{ Status anemia } \\
\hline Tidak anemia & 3128 & 58,0 & $38^{\#}$ & $-115-190$ & 0,620 \\
\hline Anemia & 3090 & 50,9 & & & \\
\hline \multicolumn{6}{|l|}{ Jenis kelamin bayi } \\
\hline Laki-laki & 3186 & 50,6 & $158^{¥}$ & $9-307$ & $0,030^{*}$ \\
\hline Perempuan & 3028 & 55,5 & & & \\
\hline
\end{tabular}

Keterangan: * = signifikan $(\mathrm{p}<0,05)$; $\mathrm{SD}=$ standar deviasi;

${ }^{\ddagger}=$ nilai statistik $t$-test; ${ }^{\#}=$ nilai statistik One-way ANOVA

Tabel 4. Pengaruh variabel umur, LILA, asupan protein, paritas, dan umur kehamilan ibu hamil trimester III terhadap berat lahir bayi

\begin{tabular}{lcccc}
\hline \multirow{2}{*}{\multicolumn{1}{c}{ Variabel }} & \multicolumn{4}{c}{ Berat lahir bayi (g) } \\
\cline { 2 - 5 } & Koefisien & $\mathbf{9 5 \% ~ C I ~}$ & $\mathbf{t}$ & $\mathbf{p}$ \\
\hline Umur (tahun) & 7 & $-6-20$ & 1,00 & 0,318 \\
LILA (cm) & -2 & $-29-24$ & $-0,19$ & 0,852 \\
Asupan protein (g) & 0,13 & $-3,36-3,63$ & 0,07 & 0,942 \\
Paritas (kali) & 58 & $-22-139$ & 1,44 & 0,154 \\
Umur kehamilan (minggu) & 12 & $-48-73$ & 0,39 & 0,694 \\
\hline
\end{tabular}

Keterangan: $\mathrm{p}=$ nilai signifikasi; $\mathrm{CI}=$ confidence interval; $\mathrm{t}=$ nilai statistik

Analisis multivariat dibuat dengan permodelan yang bertujuan untuk melihat pengaruh PMT terhadap berat lahir bayi dengan mempertimbangkan variabel luar dan melihat variabel mana yang mempunyai pengaruh terbesar terhadap berat lahir bayi (Tabel 6). Variabel luar yang dianalisis lebih lanjut merupakan variabel luar yang terbukti mempunyai pengaruh signifikan secara statistik terhadap berat lahir bayi berdasarkan hasil analisis bivariat yaitu jarak kehamilan dan jenis kelamin bayi serta variabel dengan variansi yang tidak homogen sehingga dikhawatirkan akan menganggu pengaruh dari PMT terhadap berat lahir bayi yaitu status ekonomi dan kepatuhan konsumsi tablet Fe. Selain itu, status anemia juga dimasukkan ke dalam analisis multivariat karena 
Hana Shafiyyah Zulaidah, dkk: Pengaruh pemberian makanan tambahan (PMT) pada ibu hamil terhadap berat lahir bayi

Tabel 5. Perbandingan berat lahir bayi berdasarkan status anemia ibu hamil trimester III pada kelompok perlakuan dan kelompok kontrol

\begin{tabular}{cllcccc}
\hline \multirow{2}{*}{$\begin{array}{c}\text { Status } \\
\text { anemia }\end{array}$} & Kelompok & Rerata & SD & $\begin{array}{c}\text { Beda } \\
\text { rerata }\end{array}$ & $\mathbf{9 5 \% C I}$ & p \\
\hline Tidak anemia & Perlakuan & 3218 & 91,2 & 177 & $-54-407$ & 0,1293 \\
& Kontrol & 3041 & 69,8 & & & \\
Anemia & Perlakuan & 3275 & 72,8 & $358^{*}$ & $177-538$ & 0,0002 \\
& Kontrol & 2917 & 54,3 & & & \\
\hline
\end{tabular}

Keterangan: *= nilai beda rerata dua kelompok signifikan

Tabel 6. Pengaruh PMT terhadap berat lahir bayi dengan mempertimbangkan variabel luar

\begin{tabular}{|c|c|c|c|c|c|c|c|}
\hline \multirow{2}{*}{ Variabel } & \multicolumn{7}{|c|}{ Koefisien } \\
\hline & Model 1 & Model 2 & Model 3 & Model 4 & Model 5 & Model 6 & Model 7 \\
\hline \multicolumn{8}{|l|}{ Kelompok } \\
\hline \multirow[t]{2}{*}{ Perlakuan } & $274^{*}$ & $243^{*}$ & $266^{*}$ & $274^{*}$ & $265^{*}$ & $273 *$ & $235^{*}$ \\
\hline & $(131-416)$ & $(100-385)$ & $(126-407)$ & $(128-421)$ & $(119-412)$ & $(130-416)$ & $(95-375)$ \\
\hline \multicolumn{8}{|l|}{ Kontrol } \\
\hline \multicolumn{8}{|l|}{ Jarak kehamilan (tahun) } \\
\hline \multicolumn{8}{|l|}{$\geq 2$} \\
\hline \multirow[t]{2}{*}{$<2$} & & $-162 *$ & & & & & $-182 *$ \\
\hline & & $(-430-106)$ & & & & & $(-446-82)$ \\
\hline \multirow{2}{*}{ Kehamilan pertama } & & $-161 *$ & & & & & $-161 *$ \\
\hline & & $(-311-(-11))$ & & & & & $(-308-(-13))$ \\
\hline \multicolumn{8}{|l|}{ Jenis kelamin bayi } \\
\hline \multicolumn{8}{|l|}{ Laki-laki } \\
\hline \multirow[t]{2}{*}{ Perempuan } & & & $-144 *$ & & & & $-149 *$ \\
\hline & & & $(-285-(-4))$ & & & & $(-287-(10))$ \\
\hline \multicolumn{8}{|l|}{ Status ekonomi } \\
\hline \multicolumn{8}{|l|}{ Tinggi } \\
\hline \multirow[t]{2}{*}{ Rendah } & & & & -5 & & & \\
\hline & & & & $(-157-148)$ & & & \\
\hline \multicolumn{8}{|l|}{ Kepatuhan tablet Fe } \\
\hline \multicolumn{8}{|l|}{ Patuh } \\
\hline \multirow[t]{2}{*}{ Tidak patuh } & & & & & -39 & & \\
\hline & & & & & $(-209-131)$ & & \\
\hline \multicolumn{8}{|l|}{ Status anemia } \\
\hline \multicolumn{8}{|l|}{ Tidak anemia } \\
\hline \multirow[t]{2}{*}{ Anemia } & & & & & & -36 & \\
\hline & & & & & & $((-178)-107$ & \\
\hline $\mathrm{N}$ & 101 & 101 & 101 & 101 & 101 & 101 & 101 \\
\hline Constanta & 2977 & 3065 & 3050 & 2976 & 2988 & 2994 & 3144 \\
\hline $\mathrm{R}^{2}$ & 0,1284 & 0,1713 & 0,1642 & 0,1285 & 0,1303 & 0,1306 & 0,2089 \\
\hline
\end{tabular}

Keterangan: *=signifikan $(\mathrm{p}<0,05) ; \mathrm{R}^{2}=$ koefisien determinasi; $\mathrm{N}=$ frekuensi

pada analisis stratifikasi terdapat perbedaan berat lahir bayi pada ibu hamil dengan anemia antara kelompok perlakuan dan kontrol. Analisis multivariabel dibuat menjadi 7 model. Model 1 dibuat untuk melihat pengaruh dari variabel bebas yaitu PMT terhadap variabel terikat yaitu berat lahir bayi. Model 2 sampai dengan model 7 dibuat untuk melihat pengaruh PMT terhadap berat lahir bayi dengan mengendalikan jarak kehamilan, jenis kelamin bayi, status ekonomi, kepatuhan konsumsi tablet $\mathrm{Fe}$, dan status anemia. Perbedaan rerata berat lahir bayi 
antara kelompok perlakuan dan kelompok kontrol pada 6 model di atas menunjukan hasil yang berbeda untuk setiap modelnya. Model yang dipilih merupakan model dengan nilai koefisien yang paling besar yaitu model 1 yang melihat pengaruh PMT tanpa harus menyamakan jarak kehamilan, jenis kelamin, status ekonomi, dan kepatuhan tablet $\mathrm{Fe}$ ibu hamil. Berdasarkan hasil analisis pada Tabel 6 juga dapat diketahui bahwa PMT dengan mengendalikan variabel luar tetap terbukti berpengaruh terhadap berat lahir bayi dan apabila dilihat dari nilai $\mathrm{R}$-square $\left(\mathrm{R}^{2}\right)$ maka pengaruh PMT terhadap berat lahir bayi akan meningkat jika variabel jarak kehamilan dan jenis kelamin dikendalikan.

\section{BAHASAN}

\section{Pemberian makanan tambahan pada ibu hamil trimester III}

Tidak terpenuhinya kebutuhan gizi selama masa kehamilan dapat menyebabkan kekurangan gizi yang berakibat kelahiran prematur, BBLR, dan lahir dengan penyulit yang dapat berujung pada kematian bayi atau lahir mati (15). Di samping itu, anemia merupakan masalah gizi ibu hamil yang menyumbang permasalahan berat lahir bayi. Hal ini karena ibu yang mengalami anemia pada saat hamil akan meningkatkan risiko ibu melahirkan bayi dengan BBLR (16). Kondisi status gizi yang kurang dipengaruhi oleh tidak terpenuhinya kebutuhan gizi ibu hamil yang meningkat dari sebelum ibu tidak hamil (2). Peningkatan kebutuhan energi dan zat gizi ini diperlukan untuk pertumbuhan dan perkembangan janin (17). Upaya yang dapat dilakukan untuk menangani gizi kurang yaitu dengan melakukan intervensi gizi (16). Upaya untuk meningkatkan gizi ibu hamil yaitu dengan PMT bagi ibu hamil sehingga kebutuhan gizi ibu selama kehamilan terpenuhi dan diharapkan ibu akan melahirkan bayi yang tidak BBLR.

Intervensi yang dilakukan dalam penelitian ini yaitu PMT berupa makanan olahan ikan. Ikan selain kaya akan protein juga mengandung omega 3 yang penting dalam perkembangan janin, vitamin B6 untuk mencegah anemia, dan zat besi yang sangat dibutuhkan oleh ibu selama masa kehamilan. Zat besi dalam ikan mudah diserap oleh tubuh sehingga konsumsi ikan selama masa kehamilan sangat dianjurkan. Dalam penelitian ini, ikan diolah menjadi produk makanan tambahan adalah ikan tuna. Ikan ini merupakan sejenis ikan yang memiliki kandungan protein yang sangat tinggi dengan lemak yang relatif rendah. Ikan tuna juga mengandung zat gizi lainnya seperti mineral (kalsium, fosfor, Fe, sodium), vitamin A (retinol), dan vitamin B (thiamin, riboflavin, dan niasin). Kandungan protein untuk setiap $100 \mathrm{~g}$ daging ikan tuna sebesar 22,6-26,2 g protein. Alasan peneliti menggunakan ikan terutama ikan tuna dibandingkan dengan sumber protein lain seperti telur karena ikan tuna mengandung protein yang hampir dua kali lipat dibandingkan dengan telur.

Pemerintah Kota Yogyakarta telah membuat suatu program PMT bagi ibu hamil, tetapi pemberian makanan ini hanya difokuskan pada ibu hamil dengan status KEK dan keadaan sosial ekonomi yang rendah. Makanan tersebut diberikan kepada ibu sebanyak satu kali untuk jangka waktu 3 bulan. Hal ini menjadi suatu masalah karena dikhawatirkan bahan makanan yang diberikan oleh pemerintah melalui puskesmas tersebut tidak hanya dikonsumsi oleh ibu hamilnya saja tetapi oleh anggota keluarga lain sehingga kurang efektif. Permasalahan gizi pada ibu hamil tidak hanya KEK saja, ibu hamil dengan anemia juga harus diperhatian gizinya karena ibu yang pada saat hamil mengalami anemia, berisiko untuk melahirkan bayi dengan BBLR. Penelitian ini memberikan makanan tambahan setiap hari selama 30 hari kepada ibu hamil trimester III. Harga satu kemasan dari produk makanan yang diberikan kepada ibu hamil ini yaitu Rp 5.000,- sampai dengan Rp 6.500,-. Harga ini masih relatif terjangkau untuk ibu dengan status ekonomi tinggi, akan tetapi bagi ibu dengan penghasilan keluarga di bawah UMR, harga tersebut jika hanya untuk makanan tambahan dan bukan makanan utama termasuk kategori cukup mahal.

\section{Pengaruh PMT terhadap berat lahir bayi}

Berdasarkan hasil analisis dapat disimpulkan bahwa terdapat perbedaan rerata berat lahir bayi antara kelompok perlakuan dan kelompok kontrol (274 g), perbedaan ini sesuai dengan yang diharapkan oleh peneliti yaitu sebesar $250 \mathrm{~g}$. Hasil penelitian ini menjawab hipotesis penelitian yaitu rerata berat lahir bayi pada 
kelompok yang diberi makanan tambahan (kelompok PMT) lebih tinggi dibandingkan rerata berat lahir bayi pada kelompok yang tidak diberi makanan tambahan (kontrol). Perbedaan rerata berat lahir bayi antara kelompok PMT dan kelompok kontrol akan semakin tinggi (358 g) apabila ibu hamil yang diberi makanan tambahan mengalami anemia pada awal penelitian. Hal ini menunjukkan bahwa PMT lebih efektif jika dilakukan pada ibu hamil dengan risiko seperti anemia. Perbedaan sebesar $274 \mathrm{~g}$ ini juga akan lebih terlihat pengaruhnya jika bayi dilahirkan dari ibu yang berisiko untuk melahirkan bayi dengan BBLR.

Pemberian makanan tambahan ini bertujuan agar ibu memiliki asupan gizi yang cukup selama masa kehamilan terutama pada umur kehamilan memasuki trimester III. Hal ini sejalan dengan penelitian di India (18) yang menyatakan bahwa asupan energi berpengaruh secara signifikan terhadap kejadian BBLR sehingga ibu yang mendapat asupan gizi yang baik akan berpeluang untuk memiliki bayi dengan berat lahir yang lebih besar. Penelitian tersebut menyatakan bahwa ibu yang memiliki asupan makanan kurang dari 1.500 kkal pada kehamilan trimester III memiliki prevalensi untuk melahirkan bayi dengan berat lahir rendah sebesar $82,7 \%$ dibandingkan ibu yang memiliki asupan makanan lebih dari 1.500 kkal. Penelitian lain juga menunjukkan bahwa asupan protein dan Fe ibu hamil selama kehamilan terutama pada trimester III berpengaruh sebesar 16,1\% terhadap berat lahir bayi. Asupan protein dan Fe yang semakin mendekati angka kecukupan gizi (AKG) akan semakin meningkatkan berat lahir bayi. Protein merupakan salah satu gizi makro yang dibutuhkan oleh ibu hamil untuk pertumbuhan dan perkembangan janin dalam kandungan (19).

Lebih lanjut, hasil analisis multivariat untuk melihat pengaruh PMT terhadap berat lahir bayi dengan mengendalikan variabel luar, menunjukkan bahwa variabel luar yang tetap berpengaruh secara signifikan terhadap berat lahir bayi adalah jarak kehamilan dan jenis kelamin. Jarak kelahiran yang terlalu dekat juga merupakan faktor risiko terjadinya anemia. Hal ini disebabkan oleh kondisi ibu masih belum pulih dan pemenuhan kebutuhan zat gizi belum optimal, tetapi sudah harus memenuhi kebutuhan nutrisi janin yang dikandung
(20). Jarak kehamilan yang terlalu dekat juga berisiko tinggi untuk ibu mengalami kekurangan gizi karena tidak ada kesempatan atau waktu untuk memulihkan kondisi tubuh setelah persalinan sebelumnya, terlebih jika ibu juga menyusui anak sebelumnya. Kekurangan gizi ini menyebabkan terjadinya gangguan pada kehamilan yang akan berdampak pada outcome kehamilan, salah satunya yaitu meningkatkan risiko terjadinya BBLR (21). Demikian juga dengan jenis kelamin yang berpengaruh secara signifikan terhadap berat lahir bayi yaitu pada bayi perempuan berat lahirnya lebih kecil $144 \mathrm{~g}$ dibandingkan berat lahir bayi laki-laki. Hasil ini sesuai dengan penelitian lain yang menyebutkan bahwa kejadian BBLR lebih tinggi pada bayi perempuan dibandingkan pada bayi laki-laki (22).

\section{Pengaruh variabel luar terhadap berat lahir bayi}

Variabel luar yang dibahas hanya variabel yang mempunyai pengaruh signifikan secara statistik terhadap berat lahir bayi yaitu variabel jarak kehamilan dan jenis kelamin bayi. Variabel umur ibu, LILA, pendidikan, pekerjaan, status ekonomi, kunjungan ANC, paritas, kepatuhan konsumsi tablet $\mathrm{Fe}$, status anemia, dan umur kehamilan pada penelitian ini tidak terbukti berpengaruh secara statistik terhadap berat lahir bayi sehingga tidak dibahas lebih lanjut.

Jarak kehamilan merupakan salah satu faktor yang mempengaruhi berat lahir bayi. Ibu yang melahirkan anak dengan jarak yang sangat berdekatan yaitu di bawah dua tahun akan mengalami peningkatan risiko terjadinya anemia dan ketuban pecah dini serta dapat melahirkan bayi dengan BBLR (23). Hasil analisis untuk melihat pengaruh jarak kehamilan terhadap berat lahir bayi menunjukan bahwa secara statistik rerata berat lahir bayi dari ibu dengan jarak kehamilan lebih dari atau sama dengan 2 tahun hanya signifikan jika dibandingkan dengan rerata berat lahir bayi dari ibu dengan kehamilan pertama. Hasil tersebut sejalan dengan hasil penelitian di Kabupaten Purworejo yang menyimpulkan bahwa jarak antar kehamilan mempunyai pengaruh yang signifikan terhadap berat lahir bayi dengan peningkatan berat lahir bayi sebesar 5,81 g setiap peningkatan satu bulan jarak kehamilan (24). Penelitian lain memperoleh hasil bahwa jarak ideal antar kelahiran adalah lebih dari 2 tahun. Hal 
ini bertujuan untuk memberi kesempatan pada tubuh dalam memperbaiki dan mempersiapkan organ-organ reproduksi untuk siap mengandung lagi (25).

Berat lahir bayi selain dipengaruhi oleh faktor ibu dan kesehatannya selama kehamilan juga dipengaruhi oleh faktor dari bayi tersebut yaitu jenis kelaminnya. Berdasarkan kurva pertumbuhan janin Lubchenco, berat lahir bayi dengan jenis kelamin laki-laki akan lebih tinggi dibandingkan dengan berat lahir bayi perempuan (26). Jenis kelamin bayi pada penelitian ini juga merupakan variabel yang terbukti berpengaruh signifikan terhadap berat lahir bayi yaitu dengan perbedaan rerata berat lahir antara bayi laki-laki dan perempuan sebesar 158 g. Hasil ini didukung oleh penelitian sebelumnya yang menunjukkan bahwa rerata berat lahir bayi dilihat menurut jenis kelamin menunjukan bahwa jenis kelamin laki-laki lebih berat 116,56 g dibandingkan dengan rerata berat lahir bayi dengan jenis kelamin perempuan (27). Penelitian lain juga menyatakan bahwa berat lahir secara konsisten terbukti lebih tinggi pada bayi laki-laki dibandingkan dengan bayi perempuan (28).

\section{SIMPULAN DAN SARAN}

Pemberian makanan tambahan pada ibu hamil trimester III meningkatkan berat lahir bayi. Pengaruh PMT terhadap berat lahir bayi akan meningkat jika variabel jarak kehamilan dan jenis kelamin dikendalikan. Perlu dilakukan upaya-upaya yang fokus pada peningkatan berat lahir bayi sehingga kejadian BBLR dapat menurun, yaitu melalui penyuluhan tentang makanan sehat dan bergizi bagi ibu hamil serta pemberian tablet $\mathrm{Fe}$ dan monitoring konsumsi tablet $\mathrm{Fe}$ secara teratur sehingga anemia pada ibu hamil dapat dicegah dan risiko BBLR dapat diturunkan. Pogram PMT kepada ibu hamil ini sebaiknya terus dilakukan, tetapi dengan rentang waktu yang lebih lama yaitu diberikan selama trimester III umur kehamilan. Penelitian selanjutnya perlu dilakukan dengan membandingkan antara berat lahir bayi dan berat janin sebelum diberikan PMT sehingga diketahui dengan pasti peningkatannya.

\section{RUJUKAN}

1. Milman N. Anemia-still a major health problem in many parts of the world!. Ann Hematol 2011;90(4):369-77.

2. Arisman. Gizi dalam daur kehidupan. ed 2. Jakarta: Buku Kedokteran EGC; 2009.

3. Karasahin E, Ceyhan ST, Goktolga U, Keskin U, Baser I. Maternal anemia and perinatal outcome. Perinatal Journal 2007;15:127-30.

4. Bappenas. Pedoman perencanaan program gerakan sadar gizi dalam rangka seribu hari pertama kehidupan (1000 HPK). Jakarta: Bappenas Republik Indonesia; 2012.

5. Dinas Kesehatan Kota Yogyakarta. Profil kesehatan Kota Yogyakarta tahun 2012. Yogyakarta: Dinas Kesehatan Kota Yogyakarta; 2013.

6. Proverawati A. Anemia dan anemia kehamilan. Yogyakarta: Nuha Medika; 2011.

7. Direktorat Bina Gizi Masyarakat. Petunjuk teknis pemberian makanan tambahan ibu hamil. Jakarta: Kementerian Kesehatan Republik Indonesia; 2010.

8. Soetjiningsih. Tumbuh kembang anak. Ranuh ING, editor. Jakarta: Penerbit Buku Kedokteran EGC; 1995.

9. Campebell D, Stanley J. Experimental and quasi eksperimental for research. Chicago: Rand Mcnally College Publising Company; 1966.

10. Lemeshow S, Lwanga SK. Sample size determination in health studies. Geneva: WHO Library Cataloguing in Publication Data; 1991.

11. Zeng L, Dibley MJ, Cheng Y, Dang S, Chang S, Kong L, Yan H. Impact of micronutrient supplementation during pregnancy on birth weight, duration of gestation, and perinatal mortality in rural western China: double blind cluster randomised controlled trial. BMJ 2008;337:a2001.

12. UNICEF \& WHO. Low birth weight: country, regional and global estimates. New York: UNICEF; 2004.

13. Taslim NA, Karya EM, Hadju V. Pengaruh pemberian makanan tambahan dan tablet besi terhadap kadar hemoglobin ibu hamil yang menderita kurang energi kronik di Kabupaten Takalar, Sulawesi Selatan. Medical Nusantara 2006;26:24-9.

14. BPS. Penduduk berumur 15 tahun keatas menurut pendidikan tertinggi yang ditamatkan dan kegiatan seminggu yang lalu. Jakarta: Badan Pusat Statistik Republik Indonesia; 2010.

15. Notoatmodjo S. Kesehatan masyarakat. Jakarta: Rineka Cipta; 2007. 
16. UNICEF Indonesia. Gizi ibu dan anak. Ringkasan kajian UNICEF Indonesia. [series online] 2012 [cited 30 Januari 2013]. Available from: URL: http://www.unicef.org/ indonesia/id/A6_-_B_Ringkasan_Kajian_Gizi.pdf

17. Adriani M, Wirjatmadi B. Peranan gizi dalam siklus kehidupan. Jakarta: Kencana Prenada Media Group; 2012.

18. Rao B, Aggarwal AK, Kumar R. Dietary intake in third trimester of pregnancy and prevalence of LBW: a community-based study in a rural area of Haryana. Indian J Community Med 2007;32(4):272-6.

19. Rahfiludin MZ, Julianti H, Wahyuni I. Hubungan asupan zat gizi makro dan mikro ibu hamil trimester III dengan status antropometri bayi lahir. Semarang: Universtas Diponegoro; 2004.

20. Razzaque A, Da Vanzo J, Rahman M, Gausia K, Hale L, Khan MA, Mustafa AH. Pregnancy spacing and maternal morbidity in Matlab, Bangladesh. Int J Gynaecol Obstet 2005;89(Suppl 1):S41-9.

21. Conde-Agudelo A, Rosas-Bermúdez A, Kafury-Goeta AC. Birth spacing and risk of adverse perinatal outcomes: a meta-analysis. JAMA 2006;295(15):1809-23.

22. Azhar BS, Monirujjaman M, Islam KS, Afrin S, Hossain MS. Sex, conception interval, gestational age, apgar score, and anthropometric surrogates in relation to birth weight of Bangladeshi newborns: a cross-sectional study. ISRN Public Health, 2013. [series online] 2013 [cited 22 Januari 2014]. Available from: URL: http://dx.doi. org/10.1155/2013/405725

23. Katharina K, Oktaviani I. Faktor-faktor yang mempengaruhi berat badan bayi lahir di Kabupaten Lampung Tengah tahun 2011. Jurnal Kesehatan 2011;IV(2).

24. Aswita. Pengaruh jarak antar-kehamilan dan metode kontrasepsi pil terhadap berat bayi lahir di Kabupaten Purworejo Jawa Tengah (Analisa Data Survailan LPKGM 1996 s/d 1998). Yogyakarta: Universitas Gajah Mada; 2010.

25. Rose W. Panduan lengkap perawatan kehamilan. Jakarta: Dian Rakyat; 2007.

26. Lubchenco LO, Hansman C, Dressler M, Boyd E. Intrauterine growth as estimated from liveborn birthweight data at 24 to 42 weeks of gestation. Pediatrics 1963;32:793-800.

27. Yuliva, Ismail D, Rumekti D. Hubungan status pekerjaan ibu dengan berat lahir bayi di RSUP. Dr. M. Djamil Padang. Berita Kedokteran Masyarakat 2009;25(2):96-108.

28. Vliet GV, Liu S, Kramer MS. Decreasing sex difference in birth weight. Epidemiology 2009;20(4):622. 